\title{
Polemik Arah Kiblat dan Solusinya dalam Perspektif al-Qur'an
}

\author{
Ngamilah \\ Widya Iswara Balai Diklat Keagamaan Semarang \\ Email:ngamilahwi@gmail.com
}

\begin{abstract}
Abstrak
Polemics Qibla kept rolling in the middle of the community, and also triggered by the errata Fahwa Indonesian Ulema Council (MUI) number 03 of 2010 on the Qiblah which among dictum states that lies geographically Indonesia is located in the eastern part of the Kaaba/Mecca, the mecca of the people Islam Indonesia is facing westward. Recently, the debate about the direction of Qibla is getting warmed up. Not only in certain areas, but has become a national issue. In determining the Qibla direction, no one tried to find the direction of Qibla to be exactly facing the Ka'aba ('ain al-Ka'bah) so it should take a position toward the northwest, and some are found quite facing him alone (jihhah al-ka 'bah), namely the west and prayers continue to be valid. Their reality thereby causing confusion among Indonesian Muslims. Given this reality it needed the guidance and explanation can assuage the anxiety of the people. Al-Quran and al-Sunnah be tumpuhan Qibla direction in the resolution of issues among the people. This article by referring to the interpretation and understanding of the verses of the Koran and the Sunna associated with the direction of Qibla, will try to enlighten people to the problems associated with determining the qibla direction
\end{abstract}

Polemik arah kiblat terus bergulir di tengah-tengah masyarakat, dan juga dipicu oleh adanya ralat Fahwa Majlis Ulama Indonesia (MUI) nomor 03 tahun 2010 tentang Kiblat yang diantara diktumnya menyebutkan bahwa letak georafis Indonesia yang berada di bagian timur Kabah/Mekkah, maka kiblat umat Islam Indonesia adalah menghadap ke arah barat. Belakangan ini, polemik mengenai arah kiblat semakin menghangat. Bukan hanya di daerah tertentu, melainkan sudah menjadi isu nasional. Dalam penentuan arah kiblat, ada yang berusaha mencari arah kiblat yang harus persis menghadap ke Ka'bah ('ain al-ka'bah) sehingga harus mengambil posisi arah barat laut, dan ada pula yang berpendapat cukup menghadap arahnya saja (jihhah al$\left.k a^{\prime} b a h\right)$ yaitu arah barat dan shalatnya tetap sah. Adanya realitas yang demikian menyebabkan kebingungan di antara umat Islam Indonesia. Lebih jauh itu polemik arah kiblat membawa dampak pada perpecahan di kalangan umat Islam itu sendiri. Dengan adanya realitas ini maka diperlukan adanya arahan dan penjelasan yang dapat meredakan kegelisahan umat dan menyatukan umat kembali. Al-Qur'an dan al-Sunnah menjadi tumpuhan dalam penyelesaian persoalan arah kiblat di kalangan umat. 
Artikel ini dengan merujuk penafsiran dan pemahaman terhadap ayat al-Qur'an dan al-Sunnah yang terkait dengan arah kiblat, akan mencoba memberikan pencerahan terhadap persoalan umat terkait dengan penentuan arah kiblat tersebut.

Keywords: Polemik, arah kiblat, solusi al-Qur'an.

\section{Pendahuluan}

Dampak kamajuan ilmu pengetahuan dan teknologi telah membawa banyak kemudahan kepada umat manusia, termasuk umat Islam dalam melaksanakan ibadah. Di sisi lain, ia juga membawa ekses yang menimbulkan perbedaan dilingkungan masyarakat. Perbedaan pada dasarnya adalah keniscayaan bagi setiap insan. Namun, ketika perbedaan itu menyentuh hal-hal dasar dalam kehidupan, misalnya dalam masalah keagamaan, maka ia patut disikapi secara arif. Salah satu perbedaan yang menyentuh masalah keagamaan adalah perbedaan penentuan arah kiblat. Pasca bencana gempa 30 September 2009 di Sumatra Barat arah kiblat diperdebatkan oleh sebahagian mubaligh dan tokoh umat, ada isyu miring yang menyebut bahwa terjadi pergeseran pada bumi, sehingga arah kiblat juga harus diganti. Akibatnya dalam masyarakat ada jamaah yang sampai pada tingkat merubah arah kiblat. Masalah ini kemudian dibeberapa masjid ternyata menimbulkan keresahan dan kegaduhan antar jamaah. Polemik arah kiblat terus bergulir di tengah-tengah masyarakat, dan juga dipicu oleh adanya ralat Fahwa Majlis Ulama Indonesia (MUI) nomor 03 tahun 2010 tentang Kiblat yang diantara diktumnya menyebutkan bahwa letak georafis Indonesia yang berada di bagian timur Kabah/Mekkah, maka kiblat umat Islam Indonesia adalah menghadap ke arah barat.Diktum ini diralat bahwa wilayah Indonesia secara geografis terletak tidak disebelah timur kakbah persis, melainkan agak menceng ke selatan. Maka untuk wilayah Indonesia kiblatnya tidak mengarah ke arah barat persis melainkan mengarah ke barat laut. Dalam kondisi normal, menghadap kiblat merupakan salah satu syarat shahnya ibadah shalat. Belakangan ini, polemik mengenai arah kiblat semakin menghangat. Bukan hanya di daerah tertentu, melainkan sudah menjadi isu nasional. Tulisan, ceramah dan diskusi resmi maupun tidak,telah banyak diadakan untuk membahas masalah ini. Ada yang berbicara berdasarkan ilmu, namun tidak sedikit yang berbicara berdasarkan emosional belaka. Polemik arah kiblat

Orang yang melaksanakan shalat tidak lepas dari dua keadaan, pertama; dapat melihat ka'bah secara langsung atau melihat makmum yang berada 
didepannya yang melihat ka'bah secara langsung. Hal ini hanya bisa terjadi apabila shalatnya di Masjid al-haram. Kedua; tidak dapat melihat ka'bah secara langsung dan tidak pula melihat makmum yang berada di depan yang dapak melihat ka'bah secara langsung. Hal ini terjadi apabila shalatnya di selain Masjid al-Haram, meskipun shalat di Makkah dan sekitarnya. Kedua keadaan ini akan menimbulkan konsekuensi hukum yang berbeda-beda, dan hal ini pula yang memunculkan perbedaan di kalangan Ulama'.

Ada dua macam penentuan arah kiblat, pertama; mencari arah kiblat yang harus persis menghadap ke Ka'bah ('ain al-ka'bah) sehingga harus mengambil posisi arah barat laut.Kedua; cukup mencari arahnya saja (jihhah al$\left.k a^{\prime} b a h\right)$, tidak harus persis seperti cara yang pertama, maka arah barat persis sudahlah cukup dan apabila shalatnya menghadap kearah barat persis, shalatnya tetap sah. Adanya realitas yang demikian menyebabkan kebingungan di antara umat Islam Indonesia, sehingga diperlukan adanya arahan dan penjelasan yang dapat meredakan kegelisahan umat.

Perintah menghadap kiblat dalam shalat di antaranya tercantum dalam al-Qur'an surat al-Baqarah [2]; 144. Dari pemahaman ayat ini pula terjadi perbedaan dalam penentuan arah kiblat dalam shalat. Artikel ini akan mencoba untuk menghadirkan berbagai ragam penafsiran terhadap ayat tersebut, di samping mengungkap berbagai pendapat para fuqaha' dalam mengsikapi penentuan arah kiblat. Untuk selanjutnya akan dikaji dengan mengedepankan nalar dan logika yang dapat diterima dan dipertanggung jawabkan.

\section{Fokus Permasalahan}

Berbagai ragam pemahaman tentang arah kiblah sebagai syarat sahnya salat bagi setiap Muslim menyebabnya terjadinya perbedaan pendapat yang berujung pada kebingungan di kalangan masyarakat. Salah satu jalan yang diharapkan dapat menjadi solusi terhadap kebingungan yang terjadi di masyarakat adalah merujuk pada pemahaman para mufassir terhadap ayat al-Qur'an yang dijadikan dasar hukum terhadap kewajiban menghadap kiblat dalam pelaksanaan shalat. Oleh karenanya penulisan makalah ini akan mengfokuskan mencari jawaban dari pertanyaan-pertanyaan; (1) Apakah pengertian dan perbedaan antara kiblat dan kakbah, (2) Bagaimanakah menghadap kiblat dalam pandangan para fuqaha' dan (3) bagaimanakah pendapat para mufasir terhadap arah kblat? 


\section{Antara Kiblat dan Kakbah}

Dalam persoalan shalat, istilah kiblat dan kakbah adalah dua istilah yang sering digunakan dalam tujuan yang sama, yaitu menunjuk arah dimana orang Islam harus menghadap ketika shalat. Di suatu tempat yang belum dihafali, jika orang akan melaksanakan shalat, orang akan bertanya kemana arah kiblatnya, atau orang akan bertanya kemana arah ka'bahnya. Memang dua istilah ini saling berhubungan, tapi sebenarnya dua hal ini merupakan istilah yang berbeda. Kiblat berasal dari kata dalam bahasa Arab; yaitu al-Qiblah, yang bermakna keadaan seorang yang menghadap. Kemudian, kata ini digunakan untuk istilah arah yang dituju seorang muslim ketika ia melaksanakan shalat ${ }^{1}$ Sedangkan Ka'bah, maknanya secara bahasa adalah setiap rumah yang berbentuk kubus. ${ }^{2}$ Namun secara etimologi, kata ka'bah lebih dikenal untuk menamai bangunan kubus yang dibangun pondasinya oleh Nabi Ibrahim dan Nabi Isma'il 'alaihimassalam. Yang saat ini bangunan tersebut berada di tengah Masjidil Haram di tanah suci Mekah ${ }^{3}$

\section{Menghadap Kiblat dalam Pandangan Fuqaha'}

Orang yang melakukan shalat terbagai dalam dua keadaan,yaitu pertama, orang yang shalat dalam posisi dapat melihat ka'bah secara langsung, yakni orang shalat di Masjidil Haram, kedua orang yang shalat dalam posisi tidak dapat melihat ka'bah secara langsung, yakni orang yang shalat di selain masjidil Haram. Kedua keadaan ini menimbulkan konskuensi hukum yang berbeda. Bagi orang yang shalat di Masjidil Haram yang dapat melihat ka'bah secara langsung, para ulama fiqih semuanya sepakat akan wajibnya menghadap 'ain al-Ka'bah. Ibnu Qudamah menjelaskan sebagai berikut;

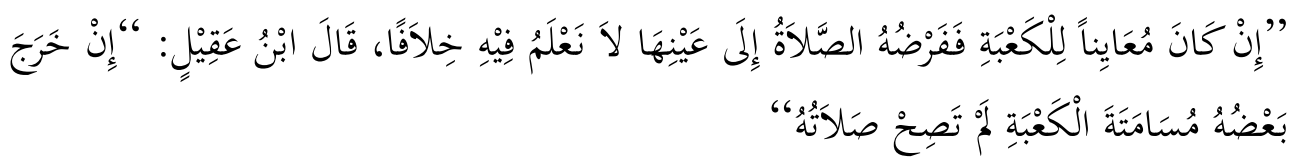

"Jika seseorang langsung melihat Ka"bah; maka wajib baginya untuk shalat menghadap ke bangunan fisik Ka'bah. Kami tidak mengetahui adanya perbedaan pendapat

${ }^{1}$ Al-Raghib al-Ashfahany, Mufradât Alfâzh al-Qur'ân, tahqiq Shafwan Dawudy,cet III, (Dimasyq: Dar al-Qalam, 2002), h. 654.

${ }^{2}$ Ibn Manzhûr, Lisân al-'Arab, cet III, Beirut, Dar Ihya' at-Turats al-'Araby, 1999, h.712

${ }^{3}$ Tartîb al-Qamus al-Muhith karya ath-Thahir az-Zawy (IV/59). 
dalam masalah ini. Ibnu 'Aqil berkata, "Iika sebagian badannya melenceng dari arah Ka'bah maka shalatnya tidak sah". ${ }^{4}$

Sedang orang yang shalat di selain masjidil Haram yang tidak dapat melihat ka'bah secara langsung, para ulama fiqih berbeda-beda pendapat dalam menghadap kiblat, apakah menghadap 'ain al-ka'bah apakah cukup mengarah ke ka'bah (jihhah al-Ka'bah). Ulama Syafi' iyah berpendapat bahwa orang yang shalat di selain masjidil Haram yang tidak dapat melihat ka'bah secara langsung, tetap wajib menghadap 'ain al-Ka'bah, tidak boleh melenceng sedikitpun. Yang dijadikan dalil oleh mereka adalah surat al-Baqarah [2];144 di mana kata "camro" dalam ayat tersebut dimaksudkan bukan sekedar arah Kiblat saja, namun harus pas ke bangunan Ka'bah ${ }^{5}$. Sedang ulama malikyah, hanafiyah dan hanabilah berpendapat bahwa orang yang jauh dari Ka'bah cukup baginya untuk menghadap ke arah Kiblat saja, tidak harus pas menghadap bangunan fisik Ka'bah. Jadi jika melenceng sedikit, maka hal tersebut tidak mengapa. Dalil yang mereka jadikan alasan untuk mendukung pendapat ini adalah sama dengan dalil yang digunakan oleh mereka yang berpendapat bahwa shalat di selain masjidil haram harus menghadap ke'ainul ka'bah yaitu surat al-Baqrah [2]; 144. Akan tetapi mereka berbeda dalam penafsiran kata samro yang terdapat dalam ayat tersebut. Kalau para ulama yang menyatakan bahwa orang shalat di selain masjidil haram tetap menghadap ke;ainul ka'bah kata samro dimaknai dengan 'ain, sedang ulama yang menyatakan bahwa orang shalat di selain masjidil haram cukup menghadap ke arah ka'bah, kata samro dimaknai jihhah.

Ketidak wajiban menghadap 'ain ka'bah bagi orang yang shalat di selain masjidil haram juga berdasarkan hadis yang berbunyi;

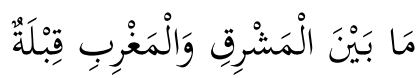

"Apa yang ada di antara timur dan barat adalah kiblat." (HR. At-Tirmizi dan Ibnu Majah dari Abu Hurairah)

Ini bagi yang kiblatnya di utara atau selatan. Adapun bagi yang kiblatnya di timur atau barat (seperti Indonesia), maka semua arah antara utara dan

${ }^{4}$ Abdullah bin Abdul Muhsin at-turki, al-Mughni, (Angkara, Dâr alam al-Kutub, 2007), h. 100 .

${ }^{5}$ Al-Baihaqi, Ahkâm al-Qur'ân li al-Imam asy-Syafi'iy,taqdim al-Kautsary, (Kairo:Maktabah al-Khanjy, cet II, 1414/1994), h. 68-70 
selatan adalah kiblat. Imam al-Shon'ani terkait dengan hadis tersebut menegaskan bahwa Hadis ini menunjukkan yang wajib adalah menghadap arah Ka'bah (jihatul ka'bah), bukan menghadap ke bangunan Ka'bah (ainul ka'bah), yakni bagi orang yang tidak dapat melihat bangunan Ka'bah. ${ }^{6}$

Maka berdasarkan keterangan di atas kita bisa mengambil pemahaman bahwa permasalahan yang disebutkan oleh penanya bukanlah masalah yang perlu untuk dibesar-besarkan apalagi sampai melahirkan perpecahan, akan tetapi hendaknya kedua belah pihak bias lapang dada menerima perbedaan. Karena barangsiapa yang mengikuti bosnya karena ingin tepat menghadap ke ka'bah maka itu tidak mengapa -walaupun telah kita terangkan bahwa itu tidak wajib, dan siapa yang sekedar menghadap ke arah ka'bah (barat) juga tidak mengapa berdasarkan hadits di atas. Walapun sepantasnya salah satu dari kedua belah pihak hendaknya ada yang mengalah agar jamaah shalat di tempat tersebut bias bersatu. Apalagi para ulama mengharamkan pembentukan jamaah kedua jika pendorongnya adalah hawa nafsu dan fanatisme golongan.

Demikian Imam al-Syaukani mengaskan bahwa tidak harus tepat/eksak ke arah bangunan Ka'bah. Inilah pendapat Imam Abu Hanifah, Malik, Ahmad, dan Syafi'i (dalam salah satu riwayat). ${ }^{7}$

Berdasarkan uraian di atas Siddiq al-jawwi menegaskan bahwa bagi penduduk Indonesia yang berada di sebelah timur Masjidil Haram, pada dasarnya cukup menghadap arah Ka'bah (jihat ka'bah), yaitu ke arah Barat. Menurut kami ini sudah cukup dan sudah sah shalatnya. Kalaupun melenceng beberapa derajat, menurut kami itu dapat dimaafkan, selama masih mengarah ke Barat. Kaidah fiqih menyebutkan: Maa qaaraba al-syai'a u'thiya hukmuhu (Apa yang mendekati sesuatu, dihukumi sama dengan sesuatu itu). ${ }^{8}$

Sedangkan untuk kemungkinan kedua, yaitu kemlencengan yang disebabkan oleh faktor alam, menurut pakar astronomi ITB Dr Moedji Raharto, hanya mengubah arah kiblat kurang dari sepersejuta derajat saja. Jadi tidak mengubah arah kiblat masjid atau arah kiblat kita saat shalat di luar masjid.

\footnotetext{
${ }^{6}$ Al-Imam Muhammad bin Ismail al-kahlani al-Shan'ani. Subulus Salam, jld 1. h.134

${ }^{7}$ Imam al-Syaukani, Nail al-authar, (Libanon, Dâr al-Fikri, 1994), h.366

${ }^{8}$ Siddiq al-jawwi dalam ; http://hizbut-tahrir.or.id/2010/06/15/hukum-arah-kiblat/
} diakses 29 agustus 2016 
Namun harus diakui banyak masjid yang arah kiblatnya kurang tepat. Bukan karena pergeseran arah kiblat, melainkan karena penentuan arah kiblat sebelum pembangunannya memang tidak akurat, atau sekedar mengikuti arah kiblat masjid terdekat yang ternyata kurang akurat.

\section{Melencengnya Arah Kiblat}

Banyak ditemukan masjid yang setelah dicek arah kiblatnya ternyat melenceng, tidak mengarah ke ka'bah. Kemlencengan arah kiblat yang terjadi di sebagian masjid di Indonesia atau mungkin terjadi juga di negara-lain, disebabkan adanya dua kemungkinan. Kemungkinan pertama memang sejak awal masjid itu sudah tidak tepat arah kiblatnya. Kemungkinan kedua disebabkan oleh faktaor alam, yaitu geraknya lempeng bumi sebagimana yang menghebohkan masyarakat muslim Indonesia. Berdasarkan teori Lempeng Tektonik, lapisan terluar bumi terbuat dari suatu lempengan tipis dan keras yang masing-masing saling bergerak relatif terhadap yang lain. Gerakan ini terjadi secara terus-menerus sejak bumi ini tercipta hingga sekarang. Teori Lempeng Tektonik muncul sejak tahun 1960 an, dan hingga kini teori ini telah berhasil menjelaskan berbagai peristiwa geologis, seperti gempa bumi, tsunami, dan meletusnya gunung berapi, juga tentang bagaimana terbentuknya gunung, benua, dan samudra. Lempeng tektonik terbentuk oleh kerak benua (continental crust) ataupun kerak samudra (oceanic crust), dan lapisan batuan teratas dari mantel bumi (earth's mantle). Kerak benua dan kerak samudra, beserta lapisan teratas mantel ini dinamakan litosfer. Kepadatan material pada kerak samudra lebih tinggi dibanding kepadatan pada kerak benua. Demikian pula, elemen-elemen zat pada kerak samudra (mafik) lebih berat dibanding elemen-elemen pada kerak benua (felsik). Di bawah litosfer terdapat lapisan batuan cair yang dinamakan astenosfer. Karena suhu dan tekanan di lapisan astenosfer ini sangat tinggi, batu-batuan di lapisan ini bergerak mengalir seperti cairan (fluid). Litosfer terpecah ke dalam beberapa lempeng tektonik yang saling bersinggungan satu dengan lainnya. Ini dikarenakan adanya pergerakan lempeng bumi. ${ }^{9}$

Untuk kemungkinan pertama, yang melencengnya sudah sejak awal dan kemlencengannya besar yang tidak mengarah ke masjid al-haram bahkan mlenceng dari posisi Tanah Haram maka setelah diketahui kemlencengan tersebut haru segera dibetulkan. Akan tetapi kalau kemlencengannya tidak

\footnotetext{
${ }^{9}$ http://www.facebook.com/topic.php?uid=53093482741\& topic=11824
} 
sampai keluar dari Tanah Haram, maka hal ini sebagian ulam tidak menganjurkan untuk merubahnya. ${ }^{10}$ Adapun untuk kemungkinan kedua yaitu kemlencengan yang disebabkan bergeraknya lempeng bumi, menurut Dr. Amien Widodo ilmuwan pakar gempa mengungkapkan bahwa dalam kondisi negeri yang sering terlanda gempa seperti Indonesia, pergerakkan lempeng bumi dapat menyebabkan terjadi pergeseran muka bumi hingga mencapai $7 \mathrm{~cm}$ per tahun. Oleh karenanya sebagai negeri kepulauan yang terletak pada lokasi sabuk "Ring of Fire” di kawasan Asia-Pasifik yang memiliki tingkat aktivitas kegempaan yang sangat tinggi, maka Indonesia sebagai negeri yang mayoritas penduduknya beragama Islam pantas untuk menyadari adalah sangat mungkin terjadi penyimpangan terhadap kiblat di setiap lokasi tempat berdirinya masjid. ${ }^{11}$

Berdasarkan hasil kajian sejumlah ilmuwan ahli ilmu kebumian dari LIPI pun memang pernah menyiarkan temuan terdapat pergeseran permukaan bumi rata-rata hingga $/+3 \mathrm{~cm}$ per tahun berdasar hasil pengukuran lapangan pada wilayah kawasan Sumatera dan Jawa yang memang mengalami dampak tumbukan diantara lempeng Australia dan lempeng Asia. Demikian juga hasil penelitian Evi Dahliyatin Nuroini, seorang mahasiswi Fakultas Syari ah. Jurusan Al-Ahwal Al-Syakhshiyyah. Universitas Islam Negeri Maulana Malik Ibrahim Malang, dalam Skripsinya yang berjudul "Pengaruh Pergeseran Lempeng Bumi Terhadap Penentuan Arah Kiblat Masjid-Masjid di Kota Yogyakarta”, menunjukkan bahwa pergeseran lempeng bumi dapat mempengaruhi arah kiblat, dengan perubahan lintang dan bujur tempat pada kisaran satuan detik dengan kurun waktu 7 tahun. Perubahan tersebut bisa diketahui dengan adanya selisih antara data lintang dan bujur tempat tahun 2010 dikurangi dengan data lintang dan bujur tempat tahun 2003. Karena lintang dan bujur tempat berubah, maka hasilnya juga mempengaruhi azimuth kiblat ${ }^{12}$

\section{Arah Kiblat dalam Fatwa MUI}

Dalam diktum fatwa MUI No. 03 Tahun 2010 tentang kiblat disebutkan bahwa; Pertama, tentang ketentuan hukum. Dalam kententuan hukum tersebut disebutkan bahwa: (1) Kiblat bagi orang shalat dan dapat melihat Ka bah adalah menghadap ke bangunan Ka bah (Ain al- Ka' bah). (2) Kiblat bagi orang yang

\footnotetext{
${ }^{10}$ Alasan untuk hal ini akan dijelaskan pada uraian-uraian berikutnya.

${ }^{11}$ Triton PB, Sejarah Bumi dan Bencana Alam, (Yogyakarta: Tugu Publisher, 2009), h. 99

12 http://catatanwacana.blogspot.co.id/2013/05/pengaruh-pergeseran-lempengbumi.html, diakses 7 September 2016
} 
shalat dan tidak dapat melihat Ka bah adalah arah Ka bah (Jihad al-ka' bah). (3). Letak georafis Indonesia yang berada di bagian Timur Ka bah/mekkah, maka kiblat umat Islam Indonesia adalah menghadap ke arah Barat. ${ }^{13}$ Berkaitan dengan fatwa tersebut MUI merekomendasikan agar bangunan masjid/ musalah di Indonesia sepanjang kiblatnya menghadap ke arah Barat, tidak perlu diubah, dibongkar, dan sebagainya. Namun fatwa MUI No. 03 Tahun 2010 tersebut mendapat respons dan protes dari kalangangan masyarakat, khususnya golongan Syafi i yang menilai bahwa fatwa MUI No. 03 Tahun 2010 tersebut tidak tepat karena seharusnya arah kiblat menghadap ke Barat laut. Dasar pertimbangannya adalah karena letak geografi Indonesia. Maka secara umum kiblat menghadap ke Barat laut bukan ke Barat. Fatwa Majelis Ulama Indonesia (MUI) No. 03 Tahun 2010 tentang kiblat ternyata masih salah. Dalam fatwa itu menyebutkan letak geografis Indonesia yang berada di bagian Timur Makkah sehingga arah kiblat menghadap ke arah barat. Padahal, berdasarkan hasil penelitian dari ilmu falak dan astronomi, arah yang ditentukan oleh MUI justru menghadap ke Afrika, Somalia Selatan, Kenya dan Tanzania. Menurut kajian ilmu ini, arah Indonesia tidak persis di Timur Makkah. Arah kiblat yang benar adalah menghadap ke Barat laut dengan kemiringan bervariasi, sesuai letak geografis wilayah tempat masjid berada.

Pelurusan arah kiblat tidak harus dengan merombak bangunan masjid.melainkan, cukup dengan menyesuaikan garis saf salat dengan kiblat yang benar.karena itu, MUI menghimbau agar semua wilayah di Indonesia harus menyesuaikan arah kiblat sesuai dengan ralat dari fatwa MUI tersebut. Alasannya adalah karena Indonesia terletak tidak di Timur pas arah Ka' bah tapi agak ke Selatan, jadi arah kiblat kita juga tidak pas ke Barat tetapi agak sedikit mengarah ke arah Barat laut. Atas dasar ini, maka Majelis Ulama Indonesia (MUI) kemudian meralat fatwa No. 3 Tahun 2010 dengan dikeluarkannya fatwa No. 5 Tahun 2010 dengan menyebutkan bahwa arah kiblat yang sebelumnya disebutkan menghadap ke Barat kini telah direvisi dengan menghadap ke Barat laut. Penentuan arah kiblat di Indoensia sangat menentukan karena pergeseran arah kiblat sebesar 1 derajat saja bisa melencengkan arah sekitar $100 \mathrm{~km}$ dari titik Ka bah.semakin jauh dari Ka bah, maka lencengan arah kiblat semakin besar.karena itu, sangat diajurkan untuk menetapkan arah kiblat. Namun demikian, Sekretaris Komisi Fatwa Majelis Ulama Indonesia (MUI) Pusat, Hasanudin, mengatakan bahwa perbedaan yang terdapat antara Fatwa

\footnotetext{
${ }^{13}$ Jaih Mubarok, Metodologi Ijtihad Hukum Islam, (Yogyakarta: UI Press, 2002), h. 169-170.
} 
MUI No. 3 Tahun 2010 tentang kiblat dan Fatwa MUI No. 5 Tahun 2010 tentang arah kiblat saling menyempurnakan.

\section{Banyak Shalat yang Tidak Shah}

Apabila berpedoman pada pendapat yang menyatakan bahwa orang yang shalat di selain masjidil Haram meskipun tidak dapat melihat ka'bah secara langsung, tetap harus menghadap 'ainul ka'bah, maka konsekuensinya banyak muslim yang melakukan shalat tapi shalatnya tidak shah , karena tidak terpenuhinya menghadap ka'bah secara tepat. Mengapa ? Selain di Masjidil Haram, posisi shaff shalat jamaahnya lurus, tidak melengkung seperti shaff di Masjidil Haram. Shalat jamaah di masjid Nabawi misalnya, posisi shaffnya lurus yang panjangnya lebih dari seratus meter. Sementara ukuran bangunan ka'bah, panjang 13, 16 meter dan lebar 11,53 meter. Ini artinya orang yang shalat berjamaah pada shaff yang panjangnya lebih dari 100 meter, maka yang shah shalatnya hanyalah yang dapat mengarah secara tepat ke ka'bah hanya yang menempati posisi shaff sepanjang 13,16 meter (panjang ka'bah) atau 11,53 meter (lebar ka'bah), sementara yang menempati posisi shaff di luar itu tidah dapat mengarah secara tepat sebagaima gambar ilustrasi di bawah ini;

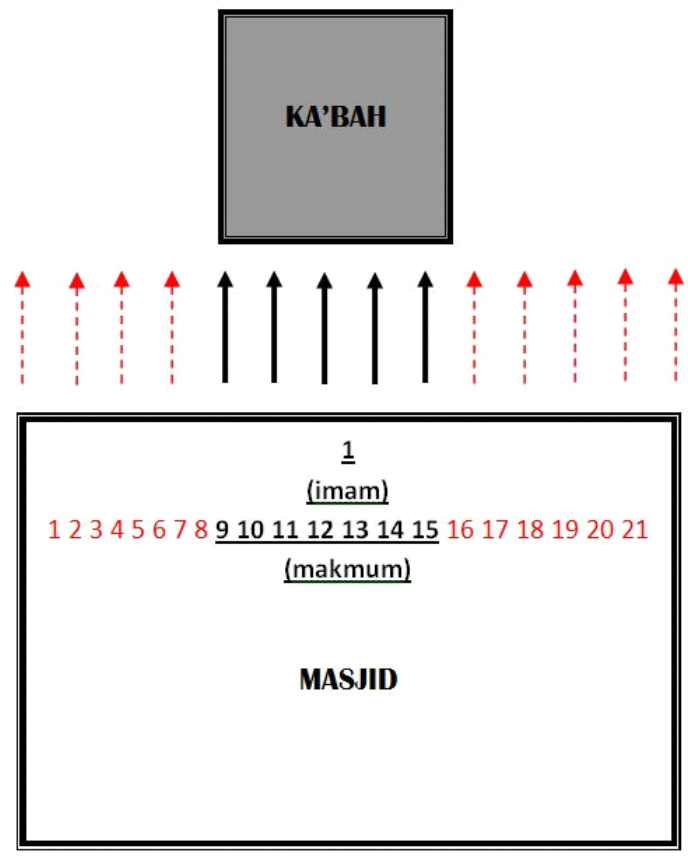

Sumber: Data terolah 
Karena itu para ulama berijma' tentang sahnya shalat orang-orang yang berada di shaf panjang, walaupun jika ditarik garis lurus tidak akan pas mengenai fisik Ka'bah senagaimana dinyatakan Imam Ibn Rajab sebagai berikut;

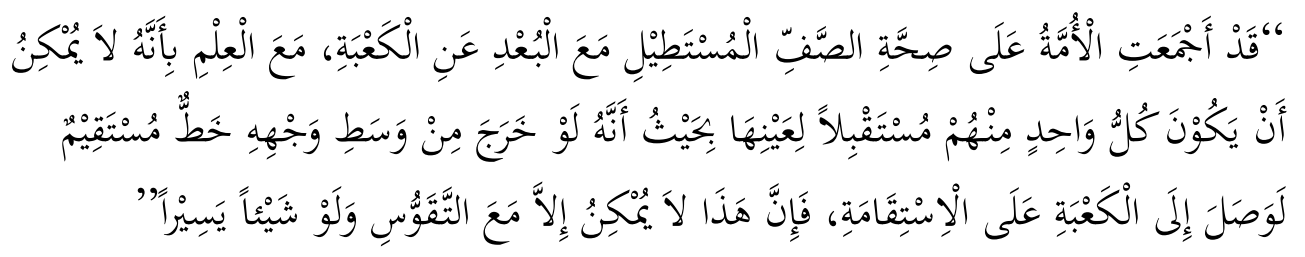

"Umat telah bersepakat tentang sahnya shalat shaf panjang yang jauh dari Ka'bah. Padahal telah maklum bahwa tidak mungkin semua dari mereka menghadap pas ke fisik bangunan Ka'bah. Dengan kata lain jika ditarik garis lurus di depan mukanya maka akan sampai tepat ke Ka'bah. Ini tidak mungkin terjadi, melainkan pasti akan melenceng walaupun sedikit". ${ }^{14}$

\section{Qiblat dalam al-Qur'an}

Qiblat sebagai arah yang dituju oleh setiap muslim dalam melaksanakan shalat, al-Qur'an menggunakan kata masjid al-Haram sebagai mana dinyatakan dalam surat al-Baqarah [2];144

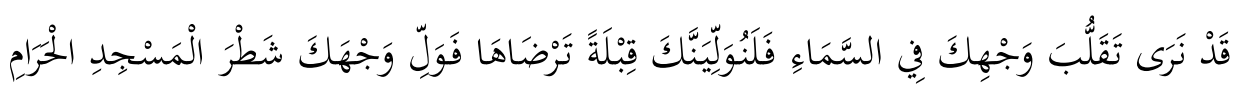

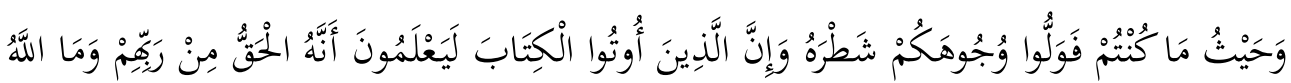

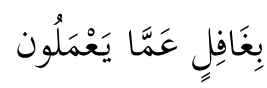

"Sungguh kami (sering) melihat mukamu menengadah ke langi, maka sungguh Kami akan memalingkan ke kiblat yang kamu sukai. Maka palingkanlah mukamu ke arah Masjidil Haram. Dan di mana saja kamu berada, palingkanlah mukamu ke arahnya. Dan sesungguhnya orang-orang (Yahudi dan Nasrani) yang diberi kitab (Taurat dan Injil) memang mengetahi, bahwa berpaling ke Masjidil Haram itu adalah benar dari Tuhannya; dan Allah sekali-kali tidak lengah dari apa yang mereka kerjakan”.

Ayat di atas berkaitan dengan pemindahan arah kiblat shalat dari Baitul Maqdis ke Ka'bah. Yang m melatarbelakangi turunnya ayat tersebut, terdapat perbedaan pendapat di antara para mufassirin. Akan tetapi kebanyakan mereka

${ }^{14}$ Ibn Rajab, tahqiq Thariq 'Awadhullah, Dammam, Fath al-Bâry fî Syarh Shahîh alBukhâry, Dar Ibn al-Jauzy, cet III, 1425, h. 296 
berpendapat bahwa turunnya ayat 144 surah al-Baqarah di atas berawal dari penantian Rasulullah akan turunnya perintah untuk memindah arah kiblat dari Baitul Maqdis ke Ka'bah. Pendapat ini dinyatakan oleh Imam al-Razi dalam tafsirnya dengan beberapa alasan yang di antaranya bahwa rasulullah lebih senang menghadap Ka'bah dari pada Baitul Maqdis. Kecondongan Rasulullah ini bukannya tanpa alasan, Imam al-Razi menyebut beberapa di antaranya karena kesombongan orang-orang Yahudi yang berkata bahwa Rasulullah menyalahi agama mereka, akan tetapi mengikuti kiblat mereka. Selain itu, kecenderungan rasulullah pada Ka'bah dikarenakan pula Ka'bah merupakan kiblatnya Nabi Ibrahim. ${ }^{15}$

Sementara itu, Imam Ibn Katsir dalam kitab tafsirnya menyatakan bahwa:

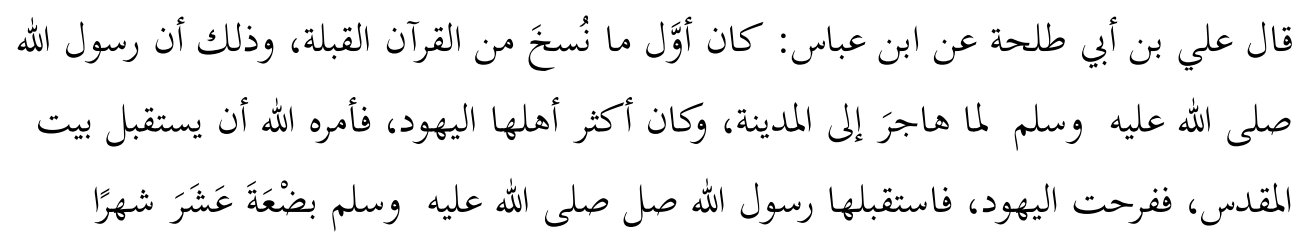

"Ali bin Abi Thalhah dari ibn 'Abbas berkat: ayat al-Qur'an yang pertama kali dimansuh adalah (ayat) tentang kiblat. Hal itu bahwanya Rasulullah ketika hijrah ke Madinah, mayoritas penduduknya Yahudi, maka Allah menyuruhnya agar menghadap ke Baitul Maqdis, maka bergembirah orang-orang Yahudi, maka Rasulullah menghadap ke Baitul Maqdis itu selama sepuluh bulan". ${ }^{16}$

Peristiwa pemindahan kiblat shalat merupakan hukum pertama yang dinasakh dalam Al-Quran. Ketika Rasulullah hijrah ke kota Madinah, karena pada waktu itu mayoritaas penduduk kota Madinah masih beragama Yahudi, Allah SWT memerintahkan beliau untuk menghadap ke arah Baitul Maqdis untuk menarik simpati penduduk Madinah yang merasa senang dengan hal tersebut. Maka, awal-awal di Madinah Rasulullah menghadap ke Baitul Maqdis selama beberapa puluh bulan. dapun sebab yang melatarbelakangi turunnya ayat tersebut, terdapat perbedaan pendapat di antara para mufassirin. Akan tetapi kebanyakan mereka berpendapat bahwa turunnya ayat 144 surah al-

${ }^{15}$ Abu Abdillah Muhammad Ibn umar al-Razi, Tafsir al-Fakhri al-Razi, al-Maktabah alSyamilah, juz 2, h. 403.

${ }^{16}$ Ismail Ibn Umar Ibn Katsir al-Dimsyiqi, Tafsir al-Quran al-Adhim, al-Maktabah alSyamilah, juz 1 h. 458 
Baqarah di atas berawal dari penantian Rasulullah akan turunnya perintah untuk memindah arah kiblat dari Baitul Maqdis ke Ka'bah. Pendapat ini dinyatakan oleh Imam al-Razi dalam tafsirnya dengan beberapa alasan yang di antaranya bahwa rasulullah lebih senang menghadap Ka'bah dari pada Baitul Maqdis. Kecondongan Rasulullah ini bukannya tanpa alasan, Imam al-Razi menyebut beberapa di antaranya karena kesombongan orang-orang Yahudi yang berkata bahwa Rasulullah menyalahi agama mereka, akan tetapi mengikuti kiblat mereka. Selain itu, kecenderungan rasulullah pada Ka'bah dikarenakan pula Ka'bah merupakan kiblatnya Nabi Ibrahim. ${ }^{17}$ Maka, Nabi Muhammad SAW menengadahkan wajahnya ke langit untuk menghadap dan berharap akan turunnya perintah memindahkan arah kiblat. Dan pada akhirnya, setelah melalui kurun waktu antara enam belas atau tujuh belas bulan sejak hijrahnya beliau ke Madinah, perintah itu pun turun dengan turunnya ayat 144 dari surah al-Baqarah tersebut.

Atas dasar ayat ini maka berubahlah arah shalat kaum muslimin ke Ka'bah, yang sebelumnya menghadap ke Baitul Maqdis (yang merupakan kiblatnya ahli kitab dari kaum yahudi dan Nasrani). Dan ternyata, berubahnya arah kiblat oleh ummat Islam ini menjadikan kaum Yahudi lebih sombong dan enggan untuk masuk Islam, dan mereka berkata;

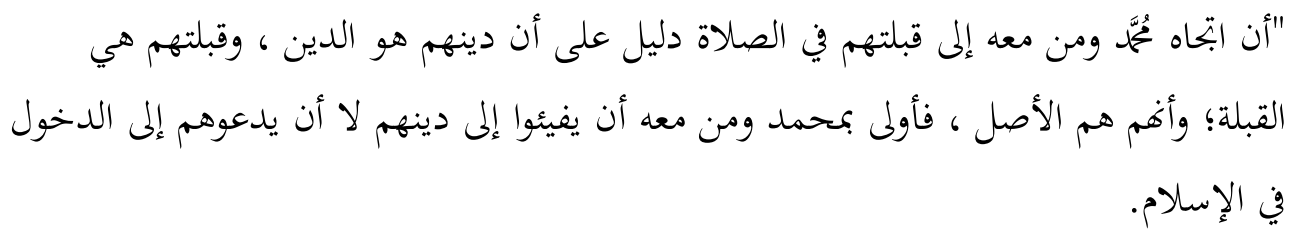

"Bahwa sesungguhnya menghadapnya Muhammad saw. dan orang-orang yang bersamanya ke arah kiblatnya orang Yahudi di dalam shalat, menunjukkan bahwa agama dan kiblat mereka adalah agama dan kiblat yang benar, serta sesungguhnya orang-orang Yahudi dan agamanya adalah yang asli. Maka, Muhammad saw. dan orang yang bersamanya justru yang harus memeluk agama orang-orang Yahudi, bukannya menyeru orang Yahudi untuk masuk Islam". ${ }^{18}$

Tidak hanya itu, orang-orang Yahudi juga menyebarkan kebohongan dan kebatilan agar kiblat Nabi Muhammad saw. dan kaum muslimin kembali

${ }^{17}$ Abu Abdillah Muhammad Ibn umar al-Razi, Tafsir al-Fakhri al-Razi, al-Maktabah alSyamilah, juz 2, h. 403

${ }^{18}$ Sayyid Quthb, Tafsir Fi Dhilal al-Quran, al-Maktabah al-Syamilah, juz 1, h.74 
ke Baitul Maqdis. Kaum Yahudi berusaha keras melenyapkan argumen yang dikeluarkan kaum muslimin berkaitan dengan pemindahan kiblat shalat. Dengan berlindung dan bersandar di balik keagungan agama Yahudi dan pada keraguan yang mereka ciptakan kepada umat Islam akan kebesaran nilai agama Islam itu sendiri.

\section{Munasabah Ayat}

Pada ayat sebelumnya, yakni ayat 143 dari surat al-Baqarah, Allah menyatakan bahwa umat Muslim merupakan umat yang terbaik di muka bumi ini (ummatan wasaman) sebagaima ditegaskan dalam ayat;

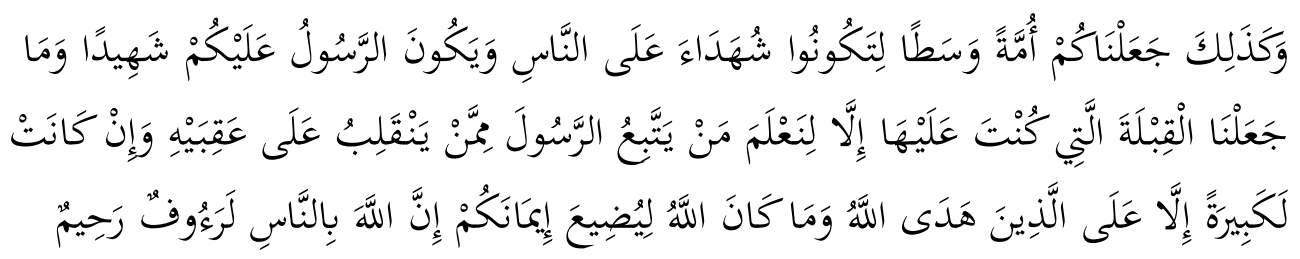

"Dan demikian (pula) Kami telah menjadikan kamu (umat Islam), umat yang adil dan pilihan agarkamu menjadi saksi atas (perbuatan) manusia dan agar Rasul (Muhammad) menjadi saksi atas (perbuatan) kamu. Dan Kami tidak menetapkan kiblat yang menjadi kiblatmu (sekarang) melainkan agar Kami mengetahui (agar nyata) siapa yang mengikuti Rasul dan siapa yang membelot.Dan sesungguhnya (pemindahan kiblat) itu terasa amat berat kecuali bagi orang orang yang telah diberi petunjuk oleh allah dan Allah tidak akan menyia-nyiakan imanmu. Sesungguhnya Allah Maha Pengasih dan maha Penyayang terhadap manusi (QS al-Baqarah [2]; 143).

Terkait dengan umat Muslim sebagai sebaik-baik umat juga dinyatakan dalam QS; ali Imron [3];110;

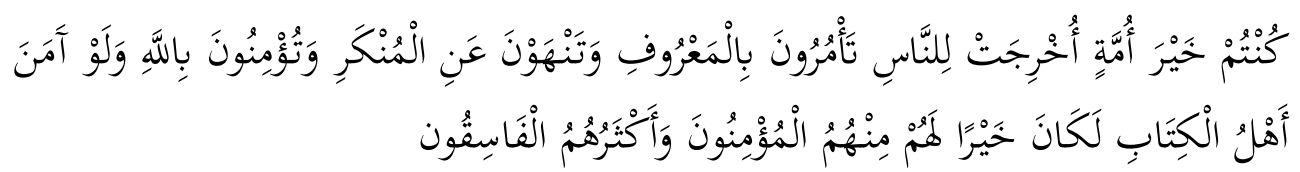

"Kamu adalah umat yang terbaik yang dilahirkan untuk manusia, menyuruh kepada yang ma'ruf, dan mencegah dari yang munkar, dan beriman kepada Allah. Sekiranya ahli kitab beriman, tentulah itu lebih baik bagi mereka, di antara mereka ada yang beriman, dan kebanyakan mereka adalah orang-orang yang fasik". 
Kaitannya menhadap kiblat dengan sebaik-baik umat adalah bahwasanya kiblat merupakan pemersatu umat Islam. Mereka melakukan shalat dengan cara yang sama, dengan arah kiblat yang sama, sehingga mereka tampil sebagai sebaik-baik umat.

\section{Faktor-faktor Perbedaan dalam Penafsiran}

Kemunculan produk tafsir secara umum dilator-belakangi oleh dua faktor, yakni faktor internal (al-'awâmil al-dâkhiliyyah) dan factor eksternal (al-'awâmil alKharijiyyah). Faktor internal meliputi faktor internal teks ayat al-Qur'an dan internal mufassir. Yang terkait factor internal teks al-Qur'an meliputi: 1) kondisi objek teks al-Qur'an itu sendiri yang memungkinkan untuk dibaca secara beragam, 2) kondisi objektif dari kata-kata (kalimah) dalam al Qur'an yang memang memungkinkan untuk ditafsirkan secara beragam, dan 3) adanya ambiguitas makna dalam al Qur'an, yang disebabkan adanya kata-kata musytarak atau bermakna ganda. Terkait dengan factor internal Mufasir meliputi perspektif atau ilmu yang ditekuni oleh seorang mufasir dan pengalaman hidup mufasir.

Faktor eksternal (al-'awâmil al-Kharijiyyah) yang meliputi: 1) adanya persinggungan dunia Islam dengan peradaban dunia dunia di luar Islam, dan 2) factor sosial, politik dan ideologi ${ }^{19}$. Kondisi intern teks al-Qur'an terkait dengan arah kiblat beberapa ayat mengisyaratkan agar dalam pelaksanaan shalat kaum muslimin menghadap ke masjidil haram. Kaitannya dengan persoalan menghadap kilat, yang menimbulkan perbedaan lebih cenderung ke persoalan adanya kata musytarak. Yang dimaksudkan dengan kata musytarak adalah kata yang memiliki lebih dari satu makna. Dalam ayat yang dijadikan dasar menghadap kiblat dalam shalat, yakni al-Qur'an surat al-Baqarah ayat 144;

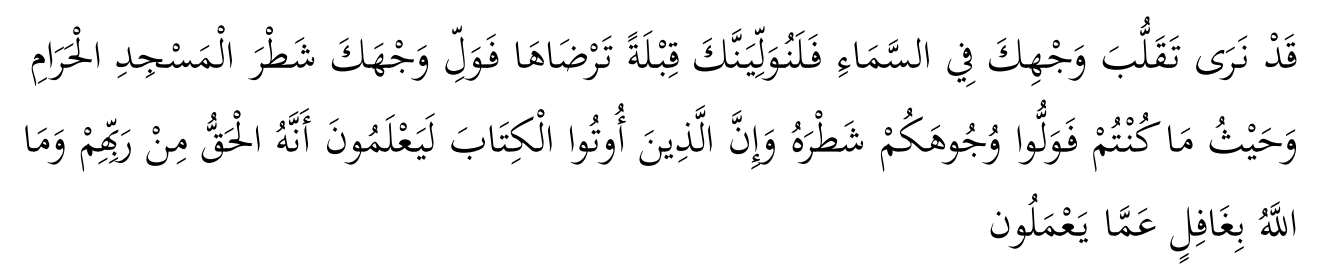

"Sungguh Kami (sering melihat) melihat mukamu menengadah ke langit, maka sungguh Kami akan memalingkan kamu ke kiblat yang engkau sukai.

${ }^{19}$ Abdul Mustaqim, Madzâhibut Tafsir, (Yogyakarta: Nun Pustaka, 2003), h. 5-6 dan 17,lihat juga Abdul Mustaqim, Dinamika Sejarah Tafsir al-Qur'an Studi Aliran-Aliran dari Periode Klasik, Pertengahan, Hingga Modern-Kontemporer (Yogyakarta: Adab Perss, 2012), h. 3 
Palingkanlah mukamu ke arah Masjidil Haram. Dan di mana saja kamu berada, palingkanlah mukamu ke arahnya. Dan sesungguhnya (orang-orang Yahudi dan Nasrani) yang diberi al-Kitab (Taurat dan Injil) memang mengetahui bahwa berpaling ke Masjidil Haram itu adalah benar dari Tuhannya, dan Allah sekali kali tidak lengah dari apa yang mereka kerjakan "

Setidaknya terdapat dua kata yang menunjukkan musytarak yaitu kata syamrah dan kata majid al-harâm. Dua kata inilah yang menimbulkan perbedaan para mufassir tentang persoalan arah kiblat.

\section{Penafsiran Ayat}

Terkait dengan kewajiban menghadap kiblat dalam ayat di atas, Imam alQortubi berpendapat bahwa setidaknya adan empat persoalan yaitu;

Pertama, kata شطر المسجد الحرام yang ditafsiri dengan arah Ka’bah para ulama berbeda pendapat tentang obyek konkret dari arah Ka'bah tersebut. Dalam kasus ini Imam al-Qurthubi meriwatkan sebuah hadits Rasul dari Ibn Abbas;

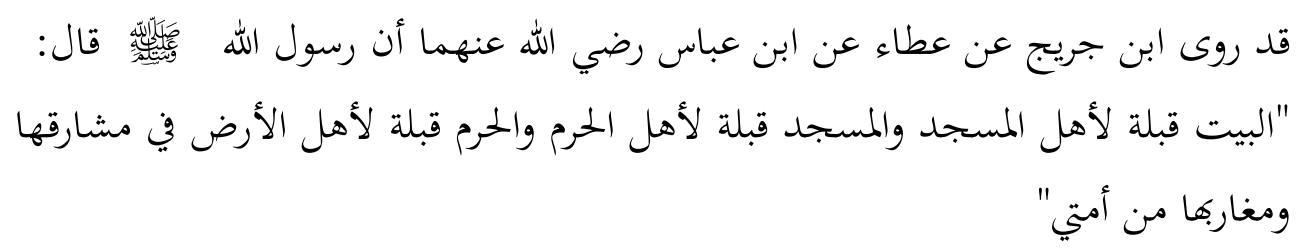

Kedua, tidak ada perbedaan pendapat di antara para ulama bahwa Ka'bah adalah arah kiblat dari segala penjuru. Para ulama juga sepakat bahwa bagi orang yang dapat melihat Ka'bah, maka ia wajib menghadap ke Ka’bah secara langsung.

Ketiga, ulama berbeda pendapat mengenai kewajiban menghadap kiblat bagi orang yang tidak dapat melihat langsung Ka'bah. Di antara ulama berpendapat wajib menghadap 'ain Ka'bah. Namun pendapat ini dibantah oleh Imam Ibn al-Arabi dan dianggap pendapat yang lemah. Karena hal ini akan berdampak pada taklif (paksaan) bagi orang yang tidak mampu.

Keempat, ayat ini menjadi hujjah yang terang bagi pendapatnya Imam Malik dan ulama yang sependapat dengannya, bahwa hukum bagi seorang mushalli adalah melihat ke depan dan bukan ke tempat sujud. ${ }^{20}$

${ }^{20}$ Abu Abdillah Muhammad al-Qurthubi, al-Jami' li Ahkam al-Qur'an, al-Maktabah alSyamilah, juz 2, h. 159-160 


\section{Kata Kunci Persoalan Arah Kiblat}

Kata Masjid al-Haram dalam ayat tersebut ditunjuk sebagai arah di mana setiap Muslim harus mengarah ketika melaksanakan shalat. Sementara kata Masjid al-Haram itu sendiri disebut dalam berbagai tempat dalam al-Qur'ân dan al-Sunnah yang memiliki makna yang berbeda-beda. Ali al-Shabuni menjelaskan bahwa kata Masjid al-Haram memiliki empat makna yaitu; Pertama; kakbah, yaitu jihhah al-ka'bah (arah ka'bah). Kata Masjid al-Haram dengan makna "ka'bah" adalah merupakan maksud dari QS. Al-Baqarah [2];144. ${ }^{21}$ Kedua; Masjid al-Haram secara keseluruhan. Kata Masjid al-Haram dengan makna bangunan Masjid alHaram secra keseluruhan sebagai mana hadis Riwayat Imam Ahmad:

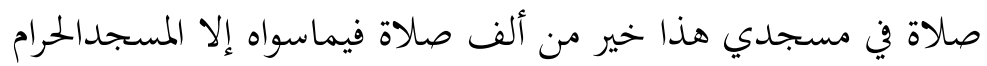

"Shalat di masjidku ini lebih utama dibandingkan seribu salat di masjid yang lain, kecuali Masjid al-Haram".

Ketiga; Kota Makkah. Kata Masjid al-Haram dengan makna kota Makkah berdasarkan surat al-Isra' [17];1

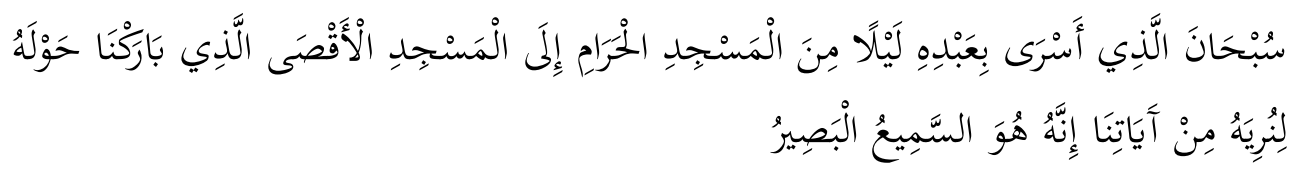

"Maha suci Allah yang telah menjalankan hamba-Nya padamalam hari dari Masjidil Haram ke Masjidil Aqsha yang telah kami berkahi sekelilingnya agar Kami perlihatkan kepadanya tanda-tanda (kebesaran) Kami. Sesungguhnya Dia adalah Maha Mendengar dan Maha Mengetahui".

Kata Masjid al-Haram dalam ayat ini dimaksudkan adalah kota Makkah, karena Rasulullah ketika Isra tidak berangkat dari Masajidil Haram, melainkan berangkat dari kota Makkah yang di dalamnya terdapat Masjidil Haram²2. Makna yang ke empat: Kota Makkah dan sekitarnya yang disebut al-Haram. Dalil yang menunjukkan makna ini adalah kata masjid al-Haram dalam surat al-Taubah [9];28;

${ }^{21}$ Shabuni, Muhammad Ali ,Rawâi' al-Bayân : Tafsîr âyât al-ahkâm min al-Qur'ân,Makkah, Dâr al-kutub al-Islamiyah,1999, h. 95

${ }^{22}$ Ibid. 


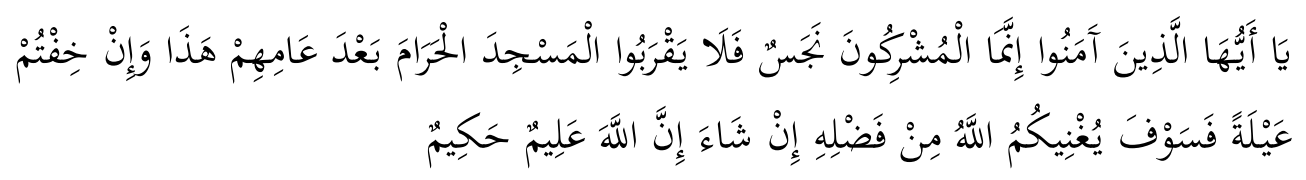

"Wahai orang-orang yang beriman Sesungguhnya orang-orang yang musyrik itu najis, maka janganlah mereka mendekati Masjidil Haram sesudah tahun ini.Jika kamu khawatir menjadi miskin maka Allah nanti akan memberimu kekayaan dari karuniaNya, jika Dia menghendaki.Sesungguhnya Allah Maha Mengetahui lagi Maha Bijaksana".

Kata masjid al-Haram dalam ayat tersebut adalah tanah haram yaitu kota Makkah dan sekitarnya dengan batas arah barat: Jalan Jeddah-Mekah, di AsySyumaisi (Hudaibiyah), yang berjarak $22 \mathrm{~km}$ dari Ka'bah. Arah selatan: Di Idha'ah Liben (Idha'ah: tanah; Liben: nama bukit), jalan Yaman-Mekah dari arah Tihamah; berjarak $12 \mathrm{~km}$ dari Ka'bah. Arah timur: Di tepi Lembah 'Uranah Barat, berjarak $15 \mathrm{~km}$ dari Ka'bah. Arah timur laut: Jalan menuju Ji'ranah, dekat dengan daerah Syara'i Al-Mujahidin, berjarak $16 \mathrm{~km}$ dari Ka'bah. Arah utara: Batasnya adalah Tan'im; berjarak 7 km dari Ka'bah. ${ }^{23}$ Karena orang musyrik tidak hanya dilarang memasuki Masjidil Haram saja, melainkan juga dilarang memasuki wilayah tanah haram secara keseluruhan ${ }^{24}$.

Sedangkan kata shamrah yang mendahului kata masjid al-haram memiliki dua makna yaitu 'ain dan jihhah. Kata 'ain dimaksudkan mengarah secar tepat, jadi 'ain al-ka'bah maksudnya mengarah ke ka'bah secara tepat. Untuk menambah pemahaman makna 'ain dapat dijelaskan dengan ilustrasi bahwa apabila mushalli diikat dengan benang dan tarik ke depan lurus, akan tepat mengenai bangunan fisik ka'bah, itulah makna 'ain. Sedang kata jihhah dimaksudkan adalah mengarah, tidak harus tepat pada sasarannya. Andai mushalli diikat dengan benang dan ditarik lurus ke depan, akan mengarah ke bangunan fisik ka'bah, meskipun melenceng dan tidak mengenai tepat pada bangunan fisik ka'bah, itulah makna jihhah. Dengan demikian apabila kata shamrah dikaitkan kata masjid al-haram yang di dalam al-Qur'an memiliki empat makna, maka akan muncul delapan kategori arah kiblat yaitu 'ain al-ka'bah, 'ain masjid alHaram, 'ain al-Makkah, 'ain al-Haram, jihhah al-Ka'bah, jihhah masjid al-Haram, jihhah al-Makkah, 'jihhah al-Haram.

${ }^{23}$ Shafiyurahman Al-Mubarakfuri, Sejarah Mekah, (Riyadh: Dar as-Salam, 1426 H), h.167,

${ }^{24}$ ibid 
Berikut gambar illustrasi dari delapan kategori tersebut

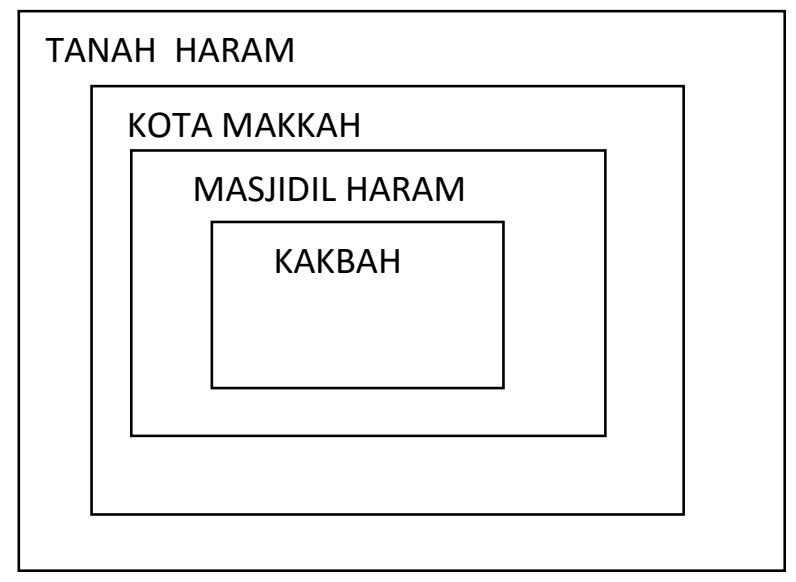

Sumber: Data terolah

\section{Toleransi dalam Menghadap Qiblat}

Bertitik tolak dari kata masjid al-haram dalam ayat di atas yang dalam penafsiran para mufassir memiliki empat makna sebagaimana dalam gambar, maka bagi orang yang melaksanakan shalat di selain masjidil haram memiliki toleransi dalam menghadap qiblat. Bentuk toleransi tersebut adalah apabila arahnya tidak mengenai bangunan fisik ka'bah, masih ada harapan dapat mengenai bangunan fisik masjidil haram yang memiliki luas $\pm 656.000 \mathrm{~m}^{2}$, dan apabila arahnya masih tidak mengenai arah bangunan masjidil haram, masih ada harapan dapat mengenai arah kota Makkah yang memiliki luas $\pm 860 \mathrm{~km}^{2}$ dan apabila masih melenceng dari arah kota Makkah, masih ada harapan dapat mengenai tanah haram yaitu dari Arah Utara Masjidil Haram 7 km, Arah Selatan Masjidil Haram $13 \mathrm{~km}$ dan Arah Barat masjidil Haram $25 \mathrm{~km}$.

Memperhatikan bentuk toleransi tersebut yang berdasarkan penafsira ayat al-Qur'an yang dijadikan sebagai dasar hukum wajibnya menghadap kiblat dalam shalat, maka semestinya tidak perlu tejadi kegelisahan dikalangan umat Islam lantaran adanya ketidak-tepatan dalam arah kiblat. Para ahli fiqih terutama fuqaha' suni yaitu Imam Mazhab Hanafi, Maliki,Syafi'i dan Hambali sepakat menegaskan bahwa masyarakat diluar tanah haram, arah kiblat mereka adalah tanah haram. Fiqh sebagai hukum syara' sebagi amaliah yang diusahakan mujtahid dari dalil yang tarenci menegaskan bahwa penentuan arah kiblat telah dilakukan ulama sejak awal mengacu kepada dalil syatral (arah masjidil haram). 
Fuqaha yang membahas hukum-hukum syari' dari dalil al-Qur'an dan hadis juga berkesimpulan bahwa kiblat bagi umat Islam yang tengah berada dalam Masjid Haram adalah a'inul ka'bah. Sedangkan kawasan Masjidil haram adalah kiblat bagi orang Mekah. Masyarakat dunia Islam diluar Masjidil haram dan tanah haram maka kawasan tanah haram adalah arah kiblat mereka. Makmur Syarif menegaskan bahwa Pandangan ulama fiqih yang demikian moderat didasarkan pada sulitnya menepatkan arah kiblat ke ainul ka'bah. Seorang ulama fiqih Ibn Abidin mengilustrasikan bahwa memastikan tetpatnya arah kiblat keainul ka'bah adalah hal yang sulit. Sebagai contoh bagi jamaah yang di dalam Masjid Madinah sekalipun itu akan sulit juga, karena panjangnya Masjid, yang jauh pasti bagi mereka yang shalat diarah ujung kanan atau ujung kiri tidak mungkin ia bisa menghadap kea'ian Ka'bah. Lebih luas lagi pendapat imam Abu Hanifah bahwa bagi orang jabal Kubis di sekitar tanah haram, shalat mereka sah jika sudah menghadap ke syatral(arah masjid haram). Begitu juga umumnya ulama fiqih mengatakan bahwa shalat akan tetap sah bila orang menghadap ke arah masjid haram, tidak mesti ke fisik ka'bah. Buya Gusrizal mengatakan bahwa ayat yang memuat kata arah kiblat (al- Baqarah [2[:144) diatas, tidaklah qathi dalalah artnya tidak satu pemahamannya. Bagi ayat-ayat yang memiliki tafsiran lebih dari satu maka disini perlu ada pendukung hadis, tidak seharusnya difatwakan, apalagi kalau fatwa itu berkaitan dengan sah atau tidak shalat. Ayat di atas ada dua kata yang masih perlu dikaji mendalam yaitu kata - syatral dan masjidil haram. Dalam kamus bahasa arab kata syatral memiliki pengertian, sebahagian (nisfu), jihah atau arah. Sedangkan makna Masjidil haram dulu adalah bangunan tanpa dinding, hanya dibatasi dengan rumahrumah orang Qurais, tentu dengan luas yang sangat sedikit sekali. Sekarang makna masjidil haram lebih luas dari itu bisa saja dengan arti daerah haram.

Apalagi kalau memperhatikan al-Qur'an surat al-Baqarah [2]; 115;

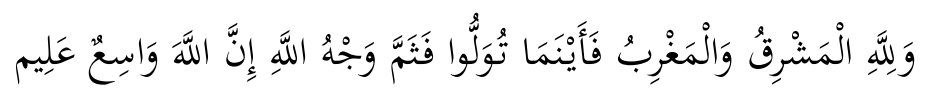

"Dan kepunyaan Allah-lah timur dan barat, Maka kemanapun kamu menghadap di situlah wajah Allah. Sesungguhnya Allah Maha Luas (rahmat-Nya) lagi Maha mengetahui"

Maka cukup membesarkan hati setiap Muslim terkait menghadap kiblat dalam shalat. Ayat tersebut telah difirmankan dengan jelas, bahwasanya baik timur ataupun barat, baik jurusan yang mana saja, semuanya itu adalah kepunyaan Allah, dan ke mana sajapun menghadap, di sana akan diterima juga oleh 
wajah Allah. Hal ini dikarenakan Allah tidak menempati sesuatu, bahkan Dia Maha Luas dan Maha Mengetahui. Oleh sebab itu, pada pokoknya ke mana sajapun kita menghadapkan muka di kala shalat, yang kita hadapi tetaplah wajah Allah, asal kita kerjakan dengan khusyu'. Akan tetapi yang menjadi persoalan adalah agama bukanlah semata-mata urusan peribadi. Agamapun adalah kesatuan seluruh insan yang sefaham dalam iman kepada Allah dan ibadat dan amal shalih. Terutama sekali dalam mengerjakan shalat. Kalau sekiranya semua orang menghadap ke mana saja tempat yang disukainya, meskipun yang disembah hanya satu, di saat itu juga mulailah ada perpecahan ummat tadi. Maka dalam Islam bukan saja cara menyembah Allah itu diajarkan dalam waktu-waktunya yang tertentu, dengan rukun dan syaratnya yang tertentu, tempat menghadapkan mukapun diatur jadi satu. Namun setidaknya dengan menyimak berbagai penjelasan tentang pemahaman kedua ayat tersebut, maka akan dapat menghilangkan kecemasan, kebingungan yang terjadi di kalangan umat Islam terkait arah kiblat.

\section{Kesimpulan}

Bertitik tolak dari uraian di atas maka dapat diambil sebagai kesimpulan sebagai berikut;

Menghadap kiblat merupakan suatu kewajiban bagi setiap muslim dalam melaksanakan shalat sebagaimana ditegaskan dalam al-Qur'an surat al-Baqarah [2];144.

Dalam pandangan mayoritas fuqahâ' menghadap qiblat secara 'ain al$K a$ 'bah hanya wajib dipenuhi oleh orang yang shalat di Masjid al-haram, sedangkan bagi orang yang shalat di luar Masjid al-haram menghadap kiblat secara 'ain al-Ka'bah tidak merupakan suatu keharussan mengingat sulitnya memenuhi 'ain al-Ka'bah. bagi penduduk Indonesia yang berada di sebelah timur Masjidil Haram, pada dasarnya cukup menghadap arah Ka'bah (jihat ka'bah), yaitu ke arah Barat.

Dalam perspektif berbagai tafsir, bagi orang yang melaksanakan shalat di selain masjid al-haram memiliki toleransi dalam menghadap qiblat. Bentuk toleransi tersebut adalah apabila arahnya tidak mengenai bangunan fisik ka'bah, masih ada harapan dapat mengenai bangunan fisik masjidil haram yang memiliki luas $\pm 656.000 \mathrm{~m}^{2}$, dan apabila arahnya masih tidak mengenai arah bangunan masjidil haram, masih ada harapan dapat mengenai arah kota Makkah yang memiliki luas $\pm 860 \mathrm{~km}^{2}$ dan apabila masih melenceng dari arah kota 
Makkah, masih ada harapan dapat mengenai tanah haram yaitu dari Arah Utara Masjidil Haram 7 km, Arah Selatan Masjidil Haram 13 km dan Arah Barat masjidil Haram $25 \mathrm{~km}$.

\section{Daftar Pustaka}

Al-Raghib al-Ashfahany, Mufradât Alfâzh al-Qur'ân, tahqiq Shafwan Dawudy,cet III, Dimasyq: Dar al-Qalam, 2002,

Bukhari, Muhammad Ibn Ismail Al-, Shahih al-Bukhari, al-Maktabah al-Syamilah Dimsyiqi, Ismail Ibn Umar Ibn Katsir Al-, Tafsir al-Quran al-Adhim, al-Maktabah al-Syamilah

Ibn Manzhûr, Lisân al-'Arab, cet III, Beirut, Dar Ihya' at-Turats al-'Araby, 1999 Maraghy, Ahmad Muthafa Al-, Tafsir al-Maraghy, diterjemah oleh Bahrun Abu Bakar, Semarang: Toha Putra, 1984

Mubarok, Jaih. Metodologi Ijtihad Hukum Islam, Yogyakarta: UI Press, 2002

Qurthubi, Abu Abdillah Muhammad Al-, al-Jami' li Ahkam al-Qur'an, alMaktabah al-Syamilah

Quthb, Sayyid, Tafsir Fi Dhilal al-Quran, al-Maktabah al-Syamilah

Shabuni, Muhammad Ali Al-, Rawâi' al-Bayân Tafsir Âyât al-Ahkâm min al-Qur'ân, Makkah, Dâr al-Kutub al-Ilmiyah, 1999

Syarjaya, H.E. Syabli, Tafsir Ayat-ayat Ahkam, Jakarta: PT Raja Grafindo Persada, 2008

Zamakhsyari, Abu al-Qasim Mahmud Al-, al-Kasysyaf, al-Maktabah al-Syamilah. 